\title{
Dignidad humana y patentabilidad de invenciones biomédicas
}

\author{
Pablo Nuevo López \\ Profesor doctor de Derecho constitucional \\ Coordinador de la Cátedra Gift \& Task de Bioética y Derecho \\ Universidad Abat Oliba CEU
}

Recibido: 02.05 .12

Aceptado: 31.05 .12

Resumen: A partir del análisis de dos Sentencias del Tribunal de Justicia de la Unión Europea sobre la Directiva relativa a la protección jurídica de las invenciones biotecnológicas, el autor aborda en este trabajo la aplicación del derecho a la dignidad humana, reconocido en el art. 1 de la Carta de derechos fundamentales de la UE, en los procesos de patentes de invenciones biotecnológicas resultado de investigaciones en las que se emplea como materia prima embriones humanos.

Palabras clave: dignidad humana, embrión, patentabilidad, Carta de derechos fundamentales, Unión Europea.

Abstract: From the analysis of two judgments of the Court of Justice of the European Union on the Directive on the legal protection of biotechnological inventions, the author addresses in this work the implementation of the right to human dignity, enshrined in art. 1 of the EU Charter of Fundamental Rights, in the process of patenting of biotechnological inventions resulting from research that used human embryos as raw material.

Key words: human dignity, patentability, Charter of fundamental rights, European Union.

Sumario: I. Introducción.-II. La Sentencia de 9 de octubre de 2001, Países Bajos/Comisión, Asunto C-377/98.- III. La Sentencia de 18 de octubre de 2011, Oliver Brüstle/Greenpeace eV, Asunto C-34/10.

IV. Dignidad de la persona e investigación biomédica.

\section{INTRODUCCIÓN}

Los avances producidos en los últimos tiempos en el ámbito de la biotecnología han permitido descubrir nuevos tratamientos para las enfermedades degenerativas, suscitando la esperanza de que sea posible curar enfermedades que, hasta ahora, parecían incurables. En la investigación biotecnológica está cobrando una importancia especial la realizada a partir de células madre, por su capacidad para evolucionar para convertirse en todo tipo de células especializadas. Dicha investigación puede hacerse a partir de células madre adultas, células obtenidas del cordón umbilical, o de células madre embrionarias.

A este respecto, se ha subrayado el enorme potencial de las células madre en biomedicina, dado que tienen una capacidad ilimitada para desarrollarse 
como células especializadas, aparte de que parece que no afectan al sistema inmunológico de la persona en que se implantan ${ }^{1}$. No obstante, la investigación con células madre de origen embrionario plantea cuestiones éticas, pues para llevar a cabo la investigación es preciso proceder a la destrucción de los embriones humanos usados en la misma.

Por otro lado, la investigación con células madre requiere de grandes inversiones económicas, inversiones que además de recursos públicos requieren del empleo de fondos privados, si bien es difícil que haya financiación privada para este tipo de investigación si no es posible obtener una explotación comercial o industrial del resultado de la misma ${ }^{2}$.

De ahí que la Unión Europea, consciente de la importancia del desarrollo de la biotecnología, adoptara en 1998 una Directiva relativa a la protección jurídica de las invenciones biotecnológicas ${ }^{3}$. En este sentido, la Comisión Europea consideró la concesión de patentes en este ámbito podría servir para incitar a las empresas europeas a invertir en el campo de la biotecnología ${ }^{4}$.

Ahora bien, la concesión de patentes a invenciones biomédicas no es una cuestión exclusivamente relativa a la explotación comercial e industrial de los resultados de la investigación científica, pues en la medida en que en dicha investigación en ocasiones se recurre a la utilización de embriones humanos es preciso analizar cuál sea el estatuto de los mismos, con objeto de dilucidar si una tal patentabilidad afecta o no a los derechos fundamentales reconocidos por la Unión Europea ${ }^{5}$, especialmente al derecho a la dignidad humana reco-

${ }^{1}$ Cfr. DEUTSCH, E. "Research and Use of Stem Cells", Revista Derecho y Genoma Humano, núm. 21, 2004, 51-65. Vid., asismismo, WITHERSPOON COUNCIL REPORT, "The Stem Cell Debates", EN The New Atlantis, núm. 34, 2012, especialmente los Apéndices A "The Scienceof Embryonic Stem Cell Research" y B “The Promise of Stem Cell Therapies".

${ }^{2}$ GARCÍA DE PABLOS, J-F. "La patentabilidad de las investigaciones biotecnológicas a la luz de la jurisprudencia comunitaria”, Gaceta Jurídica de la Unión Europea y de la Competencia, núm. 26, Nueva Época, Marzo-Abril de 2012, p. 29.

${ }^{3}$ Directiva 98/44/CE, del Parlamento y del Consejo, de 6 de julio de 1998, relativa a la protección jurídica de las invenciones biotecnológicas. DO núm. L 213, de 30/07/1998, p. 13 y ss. En el Considerando primero de esta Directiva, (en adelante, referida como Directiva 98/44/CE) se señala, expresamente, que "la biotecnología y la ingeniería genética desempeñan una función cada vez más importante en un número considerable de actividades industriales y que la protección de las invenciones biotecnológicas tendrá sin duda una importancia capital para el desarrollo industrial de la Comunidad".

${ }^{4}$ COM (2002) 545, Informe de la Comisión al Parlamento Europeo y al Consejo, de 7 de octubre de 2002, sobre Evolución e implicaciones del Derecho de patentes en el ámbito de la biotecnología y de la ingeniería genética. Sobre la necesidad de unificar criterios en este ámbito, para garantizar la competencia en el Mercado, vid. ROMEO-CASABONA, C.M. "Embryonic Stem Cell Research and Therapy at European Level: Is a common legal framework needed?", Revista Derecho y Genoma Humano, núm. 15, 2001, especialmente pp. 136-138.

${ }^{5}$ En la medida en que la Unión Europea no tiene atribuidas ni una competencia general en materia de derechos fundamentales ni competencias en materia de investigación que le 
nocido en el art. 1 de la Carta de derechos fundamentales de la Unión Europea. En este sentido, hay que recordar que de acuerdo con el Derecho de la Unión "la patentabilidad de la materia biológica se ha de ejercer respetando los principios fundamentales que garanticen la dignidad y la integridad de las personas" 6 .

Por otro lado, debe tenerse en cuenta que la biotecnología afecta a la dignidad no como amenaza para individuos aislados, sino poniendo a disposición de la técnica la naturaleza humana en su totalidad, cuestionando la imagen del hombre en la Constitución (la cualidad del hombre como sujeto, última certeza de la Constitución) ${ }^{7}$. Como ha puesto de manifiesto Benda, en relación con los retos que la biotecnología plantea al Derecho en general y a la pretensión de protección de la dignidad humana en particular, hasta ahora "no se pretendía proteger a la persona ideal plasmada en las normas, sino únicamente a aquella directamente afectada"; situación que cambia con las técnicas biomédicas, que permiten influir "en la esencia misma de la persona", pudiendo afecta "al destino de futuras generaciones respecto de las que somos responsables" ". En este sentido, se ha llegado a decir que los avances biomédicos "han puesto en cuestión nuestra imagen tradicional de nosotros mismos como seres humanos", por lo que plantean "nuevos conflictos en torno a los derechos fundamentales y al Estado constitucional" 10 .

Por estas razones la Directiva 98/44/CE excluyó de la patentabilidad tanto el cuerpo humano (art. 5) como "las invenciones cuya explotación comercial sea contraria al orden público o a la moralidad" (art. 6), incluyendo en el apartado 2 de este precepto una lista no exhaustiva de invenciones que se considerarán no patentables. De hecho, se ha llegado a sostener que se trata de una Directiva más pendiente de explicar qué se pretende regular, o con qué alcance, que de la regulación en sí misma ${ }^{11}$.

permitan establecer el régimen jurídico sustantivo que debe regir las investigaciones biomédicas, me limitaré en el presente trabajo a analizar la relación de la patentabilidad de investigaciones realizadas con embriones con la garantía de la dignidad humana del art. 1 de la Carta de derechos fundamentales de la Unión Europea.

${ }^{6}$ GARCÍA DE PABLOS, J-F. "La patentabilidad de las investigaciones biotecnológicas a la luz de la jurisprudencia comunitaria", Op. cit., pp. 28 y ss.

${ }^{7}$ SIMON, J. "La dignidad del hombre como principio regulador en la bioética", Revista Derecho y Genoma Humano, núm. 13, 2000, pp. 25-26.

${ }^{8}$ BENDA, E. "Dignidad humana y derechos de la personalidad", en: BENDA, MAIHOFER, VOGEL, HESSE, HEYDE, Manual de Derecho constitucional, Madrid, Marcial Pons, 2001, p. 135.

${ }^{9}$ DÍEZ-PICAZO, L. Ma "Bioética y legislación (Dificultades de la regulación jurídica en materia bioética)" Revista de Occidente, núm. 214, 1999, p. 11.

${ }^{10}$ RODRÍGUEZ-DRINCOURT ÁLVAREZ, J. Genoma humano y Constitución, Civitas, Madrid, 2002, pp. 28-29.

${ }^{11}$ MARTÍN URANGA, A. "Las patentes biotecnológicas: decisiones de la Oficina Europea de Patentes y del Tribunal de Justicia Europeo", Bioética y Derecho, Centre d'Estudis Jurídics i Formació Especialitzada de la Generalitat de Catalunya, Barcelona, 2004, p. 266. 
El Tribunal de Justicia ha tenido ocasión de pronunciarse en dos ocasiones en relación con la citada Directiva y la protección que otorga, a efectos del derecho de patentes, a la garantía de la dignidad humana. En una primera Sentencia ${ }^{12}$, resolviendo un Recurso de Anulación interpuesto por los Países Bajos (al que se unieron Italia y Noruega), el Tribunal de Luxemburgo tuvo que analizar si el orden público y la moralidad constituyen conceptos suficientemente claros, cuál es el significado y objeto de la excepción establecida por el artículo 6, apartado 1, de la Directiva y de qué modo afecta la Directiva a los derechos fundamentales, en particular si éstos son vulnerados por el artículo 5.2 de la Directiva. En la segunda Sentencia ${ }^{13}$, el Tribunal de Justicia ha abordado la cuestión de qué debe entenderse por embrión humano a los efectos de la Directiva, confiriendo un cierto estatuto jurídico al embrión, y extendiéndole la garantía de la dignidad humana del art. 1 de la Carta de derechos fundamentales de la Unión Europea.

En el presente trabajo procederé a analizar dichas Sentencias (epígrafes II y III), para a continuación valorarlas desde la perspectiva de la protección de la dignidad humana y de las repercusiones que pueda tener en la legislación española sobre investigación biotecnológica (epígrafe IV).

\section{LA SENTENCIA DE 9 DE OCTUBRE DE 2001, PAÍSES BAJOS/CO- MISIÓN, ASUNTO C-377/98}

\section{a) Los hechos del caso.}

Como he señalado anteriormente, la Unión Europea adoptó el 6 de julio de 1998 la Directiva 98/44/CE, relativa a la protección jurídica de las invenciones biotecnológicas. Esta Directiva fue adoptada sobre la base del entonces artículo $100 \mathrm{~A}$ del Tratado CE, teniendo por objeto armonizar la regulación en esta materia y al tiempo confiar a los Estados miembros la tarea de proteger las invenciones biotecnológicas mediante su Derecho nacional de patentes y en observancia de sus compromisos internacionales.

Para alcanzar su finalidad, la Directiva distingue en particular, dentro de las invenciones relativas a los vegetales, los animales y el cuerpo humano, entre invenciones patentables y no patentables, tratando de este modo conciliar la armonización de la protección jurídica de las invenciones biotecnológicas con el respeto a los principios de dignidad humana y protección de la integridad de la persona.

En su Recurso, el Reino de los Países Bajos señaló que actuaba por petición expresa del Parlamento de los Países Bajos, habida cuenta de la reacción generada contra las manipulaciones genéticas de animales y vegetales y contra

\footnotetext{
${ }^{12}$ Sentencia de 9 de octubre de 2001, Países Bajos/Comisión, Asunto C-377/98.

${ }^{13}$ Sentencia de 18 de octubre de 2011, Oliver Brüstle/Greenpeace eV, Asunto C-34/10.
} 
la concesión de patentes sobre los productos de procedimientos biotecnológicos que pueden favorecer tales manipulaciones ${ }^{14}$.

En el Recurso se alegaba que la Directiva había sido dictada sin base jurídica para ello, así como la falta de respeto al principio de subsidiariedad, la vulneración de la seguridad jurídica, el incumplimiento de obligaciones internacionales, la vulneración de derechos fundamentales y que no se siguió el procedimiento adecuado ${ }^{15}$. No obstante, por la naturaleza del presente trabajo únicamente abordaré las cuestiones de la moralidad y el orden público como límite a la patentabilidad de invenciones biotecnológicas y las relativas al respeto de los derechos fundamentales, particularmente el derecho a la dignidad humana.

Por lo que se refiere a la primera cuestión, en el Recurso de anulación el representante de los Países Bajos consideraba que el texto de la Directiva vulneraba el principio de seguridad jurídica al conferir a las autoridades nacionales "competencias discrecionales para la aplicación de conceptos formulados en términos generales y equívocos, como los conceptos de orden público y de moralidad que figuran en su artículo 6"16.

Esta alegación se formulaba en relación al Considerando 39 de la Directiva y al art. 6 de la misma. En efecto, el Considerando 39 de la citada Directiva establece que

"Considerando que el orden público y la moralidad se corresponden, en particular, con los principios éticos y morales reconocidos en un Estado miembro, cuyo respeto es particularmente necesario en el terreno de la biotecnología, a causa del considerable alcance de las consecuencias potenciales de la invención en este ámbito y de sus vínculos naturales con la materia viva; que tales principios éticos y morales vienen a añadirse a los controles jurídicos habituales del Derecho de patentes, independientemente del ámbito técnico a que pertenezca la invención".

Asimismo, de conformidad con el art. 6.1 de la Directiva

"Quedarán excluidas de la patentabilidad las invenciones cuya explotación comercial sea contraria al orden público o a la moralidad, no pudiéndose considerar como tal la explotación de una invención por el mero hecho de que esté prohibida por una disposición legal o reglamentaria".

\footnotetext{
${ }^{14}$ Sentencia de 9 de octubre de 2001, Países Bajos/Comisión, Asunto C-377/98, Apartado 4 .

${ }^{15}$ Cfr. FERNANDO MAGARZO, M. R. "Comentario al Recurso de anulación presentado por el Reino de Holanda contra la Directiva 98/44 relativa a la protección jurídica de las invenciones biotecnológicas", Revista Derecho y Genoma Humano, núm. 13, 2000, pp. 145-162.

${ }^{16}$ Sentencia de 9 de octubre de 2001, Países Bajos/Comisión, Asunto C-377/98, Apartado 35 .
} 
De ahí que el representante de los Países Bajos considerara que para determinar el límite de la patentabilidad la norma recurría a conceptos no suficientemente claros, lo cual podría originar problemas de interpretación a la hora de apreciar si una invención biotecnológica vulnera o no el orden público o la moralidad.

En virtud de estas consideraciones, el Reino de los Países Bajos consideraba que la Directiva, lejos de eliminar la incertidumbre jurídica en la materia objeto de regulación, la agravaba.

Por lo que respecta a la segunda cuestión, esto es, el modo en que la Directiva infringía derechos fundamentales, a juicio del demandante "la patentabilidad de elementos aislados del cuerpo humano, que se deriva del artículo 5, apartado 2, de la Directiva, equivale a una instrumentalización de la materia viva humana, contraria a la dignidad del ser humano"17.

El art. 5.2 de la Directiva establece al respecto lo siguiente:

"Un elemento aislado del cuerpo humano u obtenido de otro modo mediante un procedimiento técnico, incluida la secuencia o la secuencia parcial de un gen, podrá considerarse como una invención patentable, aun en el caso de que la estructura de dicho elemento sea idéntica a la de un elemento natural".

En consecuencia, en la medida en que a juicio del representante de los Países Bajos la Directiva establece que son patentables elementos aislados del cuerpo humano, se está procediendo a considerar la materia humana viva como un instrumento, lo cual implica una vulneración del derecho fundamental a la dignidad humana.

\section{b) La respuesta del Tribunal de Justicia.}

(i) Sobre la indeterminación de los conceptos de orden público y moralidad como límite de la patentabilidad de invenciones biotecnológicas.

El Tribunal de Justicia desestimó el argumento de los Países Bajos, considerando que la referencia de la Directiva al orden público y la moralidad no conllevaba inseguridad jurídica alguna ${ }^{18}$.

Con carácter previo, el Tribunal de Justicia reconoció que el texto de la Directiva remitía, en este punto, a lo que decidieran los Estados miembros, confiriéndoles un amplio margen de maniobra para la aplicación de este criterio de exclusión.

No obstante, a juicio del Tribunal esta remisión a los órganos nacionales para la concreción de la exclusión de patentabilidad de invenciones por infringir

\footnotetext{
tado 69 .

${ }^{17}$ Sentencia de 9 de octubre de 2001, Países Bajos/Comisión, Asunto C-377/98, Apar-

${ }^{18}$ Sobre esta Sentencia véase, también, MARTÍN URANGA, A. "Las patentes biotecnológicas: decisiones de la Oficina Europea de Patentes y del Tribunal de Justicia Europeo", Op. cit., pp. 288-293.
} 
el orden público o la moralidad lejos de crear una situación de inseguridad jurídica viene exigida por la naturaleza de la materia objeto de regulación, en la que hay una gran diversidad de opiniones y valoraciones en el conjunto de la Unión. De este modo, el Tribunal de Justicia subrayó que "dicho margen de maniobra es necesario para tener en cuenta las dificultades concretas que puede ocasionar la explotación de determinadas patentes en el contexto social y cultural de cada Estado miembro"19, recordando además que cláusulas de este tipo son habituales en el Derecho de patentes y en el Derecho internacional.

Además, el Tribunal de Justicia señaló que el margen de apreciación de que gozan los Estados no es enteramente discrecional, pues el art. 6 de la Directiva establece un doble control al mismo: por un lado, al disponer en su apartado 1 que la mera prohibición por una disposición legal o reglamentaria no convierte a la explotación de una invención en contraria al orden público o la moralidad; por otro, al incluir en el apartado 2 cuatro ejemplos de procedimientos y utilizaciones no patentables. Por tanto, queda claro que "el legislador comunitario proporciona una guía, desconocida en el Derecho general de patentes, para la aplicación de los conceptos de que se trata" 20 .

Esta guía proporcionada por el legislador comunitario excluye, así, la inseguridad jurídica, con la garantía adicional -recordada en sus Conclusiones por el Abogado General Sr. Jacobs- de la posibilidad de control judicial de la interpretación efectuada por las autoridades nacionales. En este sentido, consideró el Abogado General Sr. Jacobs que

"la aplicación por parte de las autoridades nacionales de los conceptos de orden público y moralidad queda siempre sujeta al control del Tribunal de Justicia, de modo que los Estados miembros no tienen un poder discrecional ilimitado para determinar su alcance" ${ }^{21}$.

Además, esta garantía formal de posible revisión judicial viene acompañada, asimismo, de la necesaria interpretación restrictiva de la cláusula al orden público y la moralidad como criterios de exclusión de la patentabili$\mathrm{dad}^{22}$, pues el Tribunal de Justicia ha declarado que

"el recurso, por parte de una autoridad nacional, al concepto de orden público requiere, en todo caso, aparte de la perturbación social

${ }^{19}$ Sentencia de 9 de octubre de 2001, Países Bajos/Comisión, Asunto C-377/98, Apartado 38 .

${ }^{20}$ Sentencia de 9 de octubre de 2001, Países Bajos/Comisión, Asunto C-377/98, Apartado 39.

${ }^{21}$ Conclusiones del Abogado General Sr. F. G. JACOBS, presentadas el 14 de junio de 2001, Asunto C-377/98, Reino de los Países Bajos contra Parlamento Europeo y Consejo de la Unión Europea, Apartado 101.

${ }^{22}$ Conclusiones del Abogado General Sr. F. G. JACOBS, presentadas el 14 de junio de 2001, Asunto C-377/98, Reino de los Países Bajos contra Parlamento Europeo y Consejo de la Unión Europea, Apartado 101. 
que constituye toda infracción de la ley, que exista una amenaza real y suficientemente grave que afecte a un interés fundamental de la sociedad"23.

En lo referente a estos criterios de exclusión de patentabilidad de invenciones biotecnológicas subyace un equilibrio delicado entre la afirmación de principios comunes, propios de la civilización europea, y el reconocimiento de que "algunos aspectos éticos puedan valorarse más adecuadamente en el contexto cultural de un determinado Estado miembro"24.

En cualquier caso, las consideraciones anteriores llevaron al Tribunal de Justicia a desechar el argumento del representante de los Países Bajos conforme al cual la Directiva 44/98/CE vulneraba el principio de seguridad jurídica.

(ii) Sobre la patentabilidad de elementos aislados del cuerpo humano y la instrumentalización de la materia viva humana.

Después de aceptar que en este ámbito se planteaba una cuestión relativa a los derechos fundamentales (en particular, al derecho a la dignidad humana), el Tribunal de Justicia procedió a rechazar este argumento del Representante de los Países Bajos. En efecto, para el Tribunal de Luxemburgo la regulación de la Directiva no permite instrumentalizar la materia viva humana, por lo que no vulnera el derecho a la dignidad.

El Tribunal de Justicia, para llegar a esta conclusión, puso de manifiesto cómo la Directiva protege la dignidad humana, pues el art. 5 de la misma prohíbe "que el cuerpo humano, en los diferentes estadios de su constitución y de su desarrollo, pueda constituir una invención patentable"25. Además, el Tribunal de Justicia recordó que "los elementos del cuerpo humano tampoco son de por sí patentables y su descubrimiento no puede ser objeto de protección" ${ }^{26}$.

El art. 5.2 de la Directiva establece al respecto que:

"Un elemento aislado del cuerpo humano u obtenido de otro modo mediante un procedimiento técnico, incluida la secuencia o la secuencia parcial de un gen, podrá considerarse como una invención patentable, aun en el caso de que la estructura de dicho elemento sea idéntica a la de un elemento natural".

${ }^{23}$ Sentencia del Tribunal de Justicia de 27 de octubre de 1977, Bouchereau/Reino unido, Asunto C-30/77, Apartado 35.

${ }^{24}$ Conclusiones del Abogado General Sr. F. G. JACOBS, presentadas el 14 de junio de 2001, Asunto C-377/98, Reino de los Países Bajos contra Parlamento Europeo y Consejo de la Unión Europea, Apartado 102.

${ }^{25}$ Sentencia de 9 de octubre de 2001, Países Bajos/Comisión, Asunto C-377/98, Apartado 71 .

${ }^{26}$ Sentencia de 9 de octubre de 2001, Países Bajos/Comisión, Asunto C-377/98, Apartado 72 . 
Por tanto, a la luz de esta regulación, "sólo es posible solicitar una patente para aquellas invenciones que asocien un elemento natural a un procedimiento técnico que permita aislarlo o producirlo con miras a su aplicación industrial"27.

Y es que, como recordó en sus Conclusiones el Abogado General Sr. Jacobs, "conforme al Derecho general de patentes, sólo las invenciones nuevas que impliquen actividad inventiva y sean susceptibles de aplicación industrial son patentables" 28 .

En consecuencia, ningún elemento del cuerpo humano, considerado en sí mismo, puede ser patentado, pues la Directiva excluye que tal elemento, en su entorno natural, sea objeto de apropiación.

Estas consideraciones son de aplicación a las investigaciones relativas a los genes. Si el resultado de la investigación lo constituye el descubrimiento de una secuencia de ADN, el mismo no será patentable. Para el Tribunal de Justicia,

"el resultado de dichas investigaciones sólo puede dar lugar a la concesión de una patente si la solicitud va acompañada, por un lado, de una descripción del método original de secuenciación que ha hecho posible la invención y, por otro lado, de una memoria sobre la aplicación industrial que se dará a dichas investigaciones, tal como precisa el artículo 5, apartado 3, de la Directiva"29.

En cualquier caso, y ante la posibilidad de que nuevos avances en esta materia posibiliten productos o procedimientos actualmente inimaginables que vulneren la dignidad humana, "el artículo 6 de la Directiva proporciona una garantía adicional, por cuanto califica de contrarios al orden público o a la moralidad y, por tanto, de no patentables los procedimientos de clonación de seres humanos, los procedimientos de modificación de la identidad genética germinal del ser humano y las utilizaciones de embriones humanos con fines industriales o comerciales" 30 .

A esto se añade que de acuerdo con el trigésimo octavo considerando de la Directiva precisa que la lista del art. 6 no es exhaustiva y que aquellos procedimientos cuya aplicación suponga una violación de la dignidad humana deben también quedar excluidos de la patentabilidad.

${ }^{27}$ Sentencia de 9 de octubre de 2001, Países Bajos/Comisión, Asunto C-377/98, Apartado 72 .

${ }^{28}$ Conclusiones del Abogado General Sr. F. G. JACOBS, presentadas el 14 de junio de 2001, Asunto C-377/98, Reino de los Países Bajos contra Parlamento Europeo y Consejo de la Unión Europea, Apartado 199.

${ }^{29}$ Sentencia de 9 de octubre de 2001, Países Bajos/Comisión, Asunto C-377/98, Apartado 74 .

${ }^{30}$ Sentencia de 9 de octubre de 2001, Países Bajos/Comisión, Asunto C-377/98, Apartado 76 . 
En conclusión, en opinión del Tribunal de Justicia, "la Directiva limita el Derecho de patentes de modo suficientemente estricto para que el cuerpo humano permanezca efectivamente indisponible e inalienable, garantizándose así el respeto de la dignidad humana"31.

Así, el Tribunal de Luxemburgo adoptó una postura "favorable a la protección de la dignidad humana y los derechos fundamentales en este delicado terreno" 32 .

\section{LA SENTENCIA DE 18 DE OCTUBRE DE 2011, OLIVER BRÜS- TLE/GREENPEACE EV, ASUNTO C-34/10}

\section{a) Los hechos del caso}

La Sentencia trae causa de tres cuestiones prejudiciales planteadas por el Tribunal Federal alemán (Bundesgerichtshof) mediante resolución de 17 de diciembre de 2009, en el procedimiento entre el Sr. Oliver Brüstle y Greenpeace $\mathrm{eV}$.

El Sr. Brüstle registró el 19 de diciembre de 1997 una patente, con el objeto de obtener protección jurídica para una invención biotecnológica referida a células progenitoras neuronales aisladas y depuradas, a su procedimiento de producción a partir de células madre embrionarias y a la utilización de las células progenitoras neuronales en la terapia de afecciones neurológicas.

De acuerdo con los hechos explicados en la Sentencia,

"En el folleto de la patente registrada por el Sr. Brüstle, se indica que el trasplante de células cerebrales al sistema nervioso constituye un método prometedor de tratamiento de numerosas enfermedades neurológicas. Ya se han realizado las primeras aplicaciones clínicas, en particular en pacientes afectados por la enfermedad de Parkinson".

En opinión del Sr. Brüstle, para tratar los trastornos neurológicos es necesario proceder al trasplante de células progenitoras inmaduras, células que pueden evolucionar y convertirse en cualquier tipo de células. Sobre esta cuestión, se ha de precisar que existen dos opciones para obtener células aptas para este trasplante: recurrir a la utilización de células procedentes de tejidos cerebrales de embriones humanos o, bien, recurrir a células madre embrionarias que, en tanto que células pluripotentes, pueden diferenciarse en todo tipo de células y de tejidos. La patente registrada por el Sr. Brüstle se refiere a una invención biotecnológica basada en técnicas que optan por la segunda posibilidad, es decir, la utilización de células madre embrionarias.

${ }^{31}$ Sentencia de 9 de octubre de 2001, Países Bajos/Comisión, Asunto C-377/98, Apartado 77 .

32 JIMENA QUESADA, L. Sistema Europeo de derechos fundamentales, Colex, Madrid, 2006, p. 143, en nota. 
Una vez registrada la patente, Greenpeace eV planteó ante el Tribunal Federal de Patentes un recurso solicitando la anulación de la patente del Sr. Brüstle, amparándose para ello en que la misma pretende dotar de protección jurídica a una invención biotecnológica de células progenitoras obtenidas a partir de células madre embrionarias. El mencionado Tribunal falló anulando la patente controvertida. Contra esta resolución el Sr. Brüstle interpuso un recurso ante el Tribunal Federal alemán.

Para resolver el recurso, el Bundesgerichtshof debía aplicar el art. 2 de la Ley de patentes alemana, que señala al respecto lo siguiente:

“1. No se concederán patentes por invenciones cuya explotación comercial sea contraria al orden público o a la moralidad, no pudiéndose considerar como tal la explotación de una invención por el mero hecho de que esté prohibida por una disposición legal o reglamentaria.

2. En particular, no se concederán patentes por:

[...]

3) la utilización de embriones humanos para fines industriales o comerciales;" $" 33$

Como se puede apreciar, este precepto viene a reproducir, de manera prácticamente literal, el art. 6 de la Directiva, ya citada, relativa a la protección jurídica de las invenciones biotecnológicas. En efecto, de conformidad con el art. 6 de la Directiva

1. Quedarán excluidas de la patentabilidad las invenciones cuya explotación comercial sea contraria al orden público o a la moralidad, no pudiéndose considerar como tal la explotación de una invención por el mero hecho de que esté prohibida por una disposición legal o reglamentaria.

2. En virtud de lo dispuesto en el apartado 1, se considerarán no patentables, en particular: $[\ldots]$

c) las utilizaciones de embriones humanos con fines industriales o comerciales;

En consecuencia, y dado que para resolver el recurso interpuesto por el Sr. Brüstle el Budesgerichtshof debía determinar el alcance del término "embrión", y habida cuenta que la prohibición de patentabilidad de invenciones

${ }^{33}$ Art. 2 Patentgesetz

(1) Für Erfindungen, deren gewerbliche Verwertung gegen die öffentliche Ordnung oder die guten Sitten verstoßen würde, werden keine Patente erteilt; ein solcher Verstoß kann nicht allein aus der Tatsache hergeleitet werden, dass die Verwertung durch Gesetz oder Verwaltungsvorschrift verboten ist.

(2) Insbesondere werden Patente nicht erteilt für (...) 3. die Verwendung von menschlichen Embryonen zu industriellen oder kommerziellen Zwecken; 
creadas partir de embriones humanos traía causa de la trasposición de la Directiva 98/44/CE, el Tribunal alemán procedió a plantear tres cuestiones prejudiciales ante el Tribunal de Justicia, con el objeto de que éste precisara si, a los efectos de la citada Directiva, existe un concepto uniforme de embrión derivado del Derecho comunitario o no.

El Bundesgerichtshof planteó las siguientes cuestiones prejudiciales:

“1) ¿Qué debe entenderse por 'embriones humanos' en el sentido del artículo 6, apartado 2, letra c), de la Directiva [...]?

a) ¿Están comprendidos todos los estadios de desarrollo de la vida humana desde la fecundación del óvulo o deben cumplirse requisitos adicionales, como por ejemplo alcanzar un determinado estadio de desarrollo?

b) ¿Están comprendidos también los siguientes organismos:

- óvulos humanos no fecundados a los que ha sido trasplantado el núcleo de una célula humana madura;

- óvulos humanos no fecundados que han sido estimulados mediante partenogénesis para que se dividan y sigan desarrollándose?

c) ¿Están comprendidas también las células madre obtenidas a partir de embriones humanos en el estadio de blastocisto?

2) ¿Qué debe entenderse por 'utilizaciones de embriones humanos con fines industriales o comerciales'? ¿Entra en ese concepto toda explotación comercial en el sentido del artículo 6, apartado 1, de dicha Directiva, especialmente la utilización con fines de investigación científica?

3) ¿Está excluida de la patentabilidad, con arreglo al artículo 6, apartado 2, letra c), de la Directiva [...], una información técnica también cuando la utilización de embriones humanos no constituye en sí la información técnica reivindicada con la patente, sino un requisito necesario para la aplicación de esa información:

- porque la patente se refiere a un producto cuya elaboración exige la previa destrucción de embriones humanos,

- o porque la patente se refiere a un procedimiento para el que es necesario dicho producto como materia prima?"

El Tribunal de Justicia sintetiza del siguiente modo la cuestión planteada por el Budesgerichtshof:

"El órgano jurisdiccional remitente pretende esencialmente que se determine si las células madre embrionarias humanas que sirven de materia prima para los procedimientos patentados constituyen «embriones» en el sentido del artículo 6, apartado 2, letra c), de la Directiva y si los organismos a partir de los cuales pueden obtenerse las células madre embrionarias humanas constituyen «embriones humanos» en el 
sentido de dicho artículo. A este respecto, observa que no todas las células madre embrionarias humanas que sirven de materia prima para los procedimientos patentados constituyen células totipotenciales, algunas no son sino células pluripotenciales, obtenidas a partir de embriones en el estadio de blastocisto. Se pregunta además acerca de la calificación que a la vista del concepto de embrión debe darse a los blastocistos a partir de los que también pueden obtenerse células madre embrionarias humanas" ${ }^{\prime 3}$.

\section{b) La respuesta del Tribunal de Justicia a las cuestiones prejudiciales.}

(i) Primera cuestión prejudicial: concepto de embrión a efectos del Derecho europeo de patentes de invenciones biomédicas.

En relación con la primera cuestión, esto es, qué debe entenderse por “embriones humanos" a los efectos de la Directiva 98/44/CE, el Tribunal de Justicia comienza poniendo de manifiesto que la seguridad jurídica y el principio de igualdad en la aplicación de la ley exigen que, a falta de una remisión a los Derechos nacionales para determinar el sentido y alcance de una disposición del Derecho de la Unión, ésta debe ser "objeto en toda la Unión Europea de una interpretación autónoma y uniforme".

En el mismo sentido, así lo había señalado ya el Abogado General ${ }^{35}$, Sr. Yves Bot, al afirmar que la Directiva 98/44/CE es una "Directiva de armonización", que tiene entre sus objetivos favorecer la investigación y el desarrollo en el ámbito de las biotecnologías por la vía de evitar, en el mercado interior, las diferencias legislativas y jurisprudenciales sobre esta materia entre los Estados miembros ${ }^{36}$.

Por tanto, el Tribunal de Justicia considera que es necesario dar una interpretación uniforme a escala comunitaria sobre qué debe entenderse por embrión humano a los efectos del Derecho de patentes. La problemática radica en el hecho de que ni la Directiva 98/44/CE ni el propio Derecho de la Unión aportan una definición o un contenido preciso, que permitan realizar esa interpretación. Por otra parte, el Tribunal de Justicia tampoco puede acudir a las definiciones que ofrecen las distintas legislaciones de los Estados miembros, pues no hay un consenso comunitario sobre qué es un embrión humano, existen respuestas divergentes en torno a esta cuestión. Además, como señala el propio Tribunal, debe tenerse en cuenta que se trata de un asunto especialmente polémico, en el que convergen sensibilidades religiosas, éticas y morales de muy diverso signo. Ahora bien, esta dificultad no puede implicar la

\footnotetext{
${ }^{34}$ Sentencia de 18 de octubre de 2011, Oliver Brüstle/Greenpeace eV, Asunto C-34/10, Apartado 22.

${ }^{35}$ Conclusiones del Abogado General, Sr. Yves BOT, presentadas en fecha 10 de marzo de 2011, Asunto C-34-10, Oliver Brüstle contra Greenpeace eV, Apartados 54 y 55.

${ }^{36}$ GARCÍA DE PABLOS, J-F. "La patentabilidad de las investigaciones biotecnológicas a la luz de la jurisprudencia comunitaria", $O p$. cit., p. 34.
} 
inexistencia de un sentido uniforme del término "embrión humano", pues dicha inexistencia conllevaría dejar vació de contenido el art. 6 de la Directiva 98/44/CE.

Siguiendo las Conclusiones del Abogado General, y partiendo de la base de que "la determinación del significado y del alcance de los términos no definidos por el Derecho de la Unión debe efectuarse, en particular, teniendo en cuenta el contexto en el que se utilizan y los objetivos perseguidos por la normativa de la que forman parte", el Tribunal decide acudir a una interpretación teleológica de la Directiva para determinar qué debe entenderse por embrión humano.

Así las cosas, el Tribunal de Justicia, comienza recordando cómo en la Exposición de motivos de la Directiva se incluyen constantes referencias a la dignidad humana como límite infranqueable a la investigación en el ámbito de la biotecnología ${ }^{37}$. ñala:

En efecto, en la Exposición de Motivos de la Directiva 98/44/CE se se-

"16. Considerando que el Derecho de patentes se ha de ejercer respetando los principios fundamentales que garantizan la dignidad y la integridad de las personas, que es preciso reafirmar el principio según el cual el cuerpo humano, en todos los estadios de su constitución y de su desarrollo, incluidas las células germinales, así como el simple descubrimiento de uno de sus elementos o de uno de sus productos, incluida la secuencia o la secuencia parcial de un gen humano, no son patentables; que estos principios concuerdan con los criterios de patentabilidad previstos por el Derecho de patentes, en virtud de los cuales un simple descubrimiento no puede ser objeto de una patente".

Asimismo, el Considerando $38^{\text {a }}$ de la Directiva señala que deben considerarse no patentables aquellas invenciones que contravengan "el orden público o la moralidad", señalando que esta referencia excluye la patentabilidad de aquellos procedimientos "cuya aplicación suponga una violación de la dignidad humana".

A la luz de las consideraciones contenidas en la Exposición de Motivos de la Directiva 98/44/CE, el Tribunal de Justicia concluye que "el contexto y la finalidad de la Directiva revelan así que el legislador de la Unión quiso excluir toda posibilidad de patentabilidad en tanto pudiera afectar al debido respeto de la dignidad humana" 38 . La consecuencia de la anterior afirmación es que el concepto de "embrión" contenido en la Directiva, lo es en sentido amplio.

\footnotetext{
${ }^{37}$ Sentencia de 18 de octubre de 2011, Oliver Brüstle/Greenpeace eV, Asunto C-34/10, Apartados 32 a 34 .

${ }^{38}$ Sentencia de 18 de octubre de 2011, Oliver Brüstle/Greenpeace eV, Asunto C-34/10, Apartado 34.
} 
Partiendo de las anteriores premisas, el Tribunal de Justicia no vacila al afirmar que "todo óvulo humano, a partir de la fecundación, deberá considerarse un embrión humano", precisamente porque "la fecundación puede iniciar el proceso de desarrollo de un ser humano" 39 . Pero es que además, considera que "también debe atribuirse esta calificación al óvulo humano no fecundado en el que se haya implantado el núcleo de una célula humana madura, y al óvulo humano no fecundado estimulado para dividirse y desarrollarse mediante partenogénesis", y esto porque, aun no habiendo fecundación, "son aptos para iniciar el proceso de desarrollo de un ser humano"40.

Expuesto lo anterior, y sin perjuicio de que no cuestionamos la conclusión a la que llega el Tribunal, no podemos dejar de señalar que la Sentencia no contiene una argumentación coherente que permita concluir que, en la medida en que la Directiva pretende regular la protección jurídica de las invenciones biotecnológicas desde el respeto a la dignidad humana, debe acogerse una definición de embrión humano en sentido amplio.

En este punto, a mi entender, habría sido conveniente que el Tribunal explicitara el razonamiento por el que llega a esa conclusión, sobre todo teniendo en cuenta que, como había señalado el propio Tribunal en el Apartado 30 de la Sentencia, se trata de una materia "de alcance social muy sensible" y "caracterizada por las múltiples tradiciones y sistemas de valores" de los Estados miembros.

Más acertada parece la argumentación del Abogado General en sus Conclusiones en relación con este proceso. En efecto, en su informe el Sr. Yves Bot, además de recurrir al concepto de dignidad humana de la Exposición de Motivos de la Directiva, trae a colación las propias disposiciones.

Así, en relación con la definición de embrión humano, el Abogado General comienza poniendo de manifiesto que la Directiva no aspira a definir la vida, sino el cuerpo humano ${ }^{41}$. En este sentido, el art. 5 de la Directiva protege el cuerpo humano por la vía de considerarlo no patentable, al disponer en su apartado 1 que

"El cuerpo humano en los diferentes estadios de su constitución y de su desarrollo, así como el simple descubrimiento de uno de sus elementos, incluida la secuencia o la secuencia parcial de un gen, no podrán constituir invenciones patentables".

Al centrar el asunto de la protección alrededor del cuerpo humano, ya no es necesario responder a preguntas tan polémicas como el origen de la vida

\footnotetext{
${ }^{39}$ Sentencia de 18 de octubre de 2011, Oliver Brüstle/Greenpeace eV, Asunto C-34/10, Apartado 35.

${ }^{40}$ Sentencia de 18 de octubre de 2011, Oliver Brüstle/Greenpeace eV, Asunto C-34/10, Apartado 36.

${ }^{41}$ Conclusiones del Abogado General, Sr. Yves BOT, presentadas en fecha 10 de marzo de 2011, Asunto C-34-10, Oliver Brüstle contra Greenpeace eV, Apartado 72.
} 
o sobre qué determina la adquisición de la personalidad. En este sentido, el Abogado General prosigue su argumentación considerando que el cuerpo humano, una vez existe, se desarrolla independientemente de quién lo habite ${ }^{42}$. Planteada así la cuestión, de lo que se trata es de saber a partir de qué estadio de la evolución del cuerpo humano podemos considerar que estamos, desde un punto de vista jurídico, ante un embrión ${ }^{43}$.

No obstante, antes de abordar esta cuestión, llama la atención que el Abogado General proceda a recordar los límites de la ciencia, por cuanto, si bien ésta puede dar con bastante precisión información fiable sobre el proceso biológico que va de la concepción al nacimiento, lo cierto es que, a día de hoy, es incapaz de señalar a partir de qué momento del desarrollo del no nacido comienza la persona humana ${ }^{44}$. Y es que ésta es una cuestión de naturaleza metafísica, no científica, y su respuesta dependerá de en qué se cifre la personalidad. Al margen de la anterior consideración, como pone de manifiesto acertadamente el Abogado General, Sr. Bot, sí que es posible dar una respuesta jurídica a la cuestión que subyace en el procedimiento ante el Tribunal de Justicia sin tener que recurrir a una aproximación filosófica o religiosa.

En efecto, el Abogado General pone de manifiesto que existe un criterio determinante, que no es otro que la capacidad de las células de llegar a convertirse en un cuerpo humano. Es decir, siempre que nos encontremos ante una estructura celular con capacidad para convertirse en un individuo de la especie humana, debemos considerar, a los efectos de la Directiva, que nos encontramos ante un embrión. En conclusión, las células totipotentes, que tienen como característica esencial la capacidad de convertirse en un ser humano completo, deben ser calificadas jurídicamente como embriones.

A propósito de lo anterior, el Abogado General incorpora una reflexión adicional, interesante, y es que la consideración como embrión humano no puede quedar sometida al requisito de la anidación; en contraposición a aquellos que sostienen que un embrión lo es únicamente a partir de la anidación argumentando que no todo óvulo fecundado llega a anidar en el útero y, por tanto, mientras no se produzca la anidación (necesaria para poder llegar al nacimiento) no estamos en presencia de un embrión. El Abogado General refuta las referidas posiciones señalando que el azar o la probabilidad no pueden ser fuente del Derecho. Además, arguye que la legislación en materia de reproducción humana asistida refuerza el criterio amplio de qué ha de considerarse embrión.

En efecto, y es que si excluyéramos de la consideración de embrión a la estructura celular que aún no ha anidado, se debería excluir también de esta

${ }^{42}$ Conclusiones del Abogado General, Sr. Yves BOT, presentadas en fecha 10 de marzo de 2011, Asunto C-34-10, Oliver Brüstle contra Greenpeace eV, Apartado 73.

${ }^{43}$ Conclusiones del Abogado General, Sr. Yves BOT, presentadas en fecha 10 de marzo de 2011, Asunto C-34-10, Oliver Brüstle contra Greenpeace eV, Apartado 74.

${ }^{44}$ Conclusiones del Abogado General, Sr. Yves BOT, presentadas en fecha 10 de marzo de 2011, Asunto C-34-10, Oliver Brüstle contra Greenpeace eV, Apartado 80. 
consideración a todos los que son creados en los procesos de fecundación in vitro, y lo cierto es que la legislación sobre esta materia no refleja este punto de vista, sino que atribuye la condición de embrión a los creados con la finalidad de ser implantados en el útero de una mujer con objeto de provocarle un embarazo y hacer posible, de este modo, la maternidad a personas que tienen algún impedimento para ello. Por tanto, si el que va a ser implantado es un embrión, la exclusión de dicha categoría de los que van a ser objeto de investigación no se encuentra justificada, pues el acceso a la condición jurídica de embrión dependería, únicamente, de un criterio diferenciador "de orden psicológico", diferenciación que abriría la puerta a una cultura de creación industrial de embriones destinados a generar células madre embrionarias ${ }^{45}$.

A la luz de las anteriores consideraciones, el Abogado General concluye señalando que

"Cada vez que nos encontremos en presencia de células totipotentes, cualquiera que sea el medio por el que hayan sido obtenidas, estaremos en presencia de un embrión, por lo que debe excluirse toda patentabili$\mathrm{dad}^{\prime 46}$.

Sin embargo, la respuesta que da el Tribunal de Justicia es distinta en relación con las células madre obtenidas de embriones humanos en el estadio de blastocisto. Sobre este respecto, renuncia a extender el concepto europeo uniforme de embrión, debiendo en consecuencia determinar esta cuestión el juez nacional, a la luz de los avances de la ciencia ${ }^{47}$.

En este extremo, la Sentencia se aparta de los argumentos del Abogado General. Según se ha señalado, éste parte de la consideración de que, dado que las células obtenidas de embriones en estado de blastocisto son células pluripotentes y no totipotentes, ya no pueden desarrollarse separadamente para dar lugar a un ser humano completo. Ahora bien, a pesar de subrayar esta diferencia sustancial según argumenta el Abogado General, ello no obsta para discriminar o diferenciar según el caso la condición de embrión humano, por cuanto el blastocisto no es más que un estadio del desarrollo natural de las células totipotentes y, por ende, pretender negar la condición de embrión humano al blastocisto equivaldría a "disminuir la protección del cuerpo humano en un estadio más avanzado de su evolución" ${ }^{48}$, siendo así que la Directiva 98/44/CE, en su art. 5.1, prohibió las patentes del cuerpo humano, precisa-

${ }^{45}$ Conclusiones del Abogado General, Sr. Yves BOT, presentadas en fecha 10 de marzo de 2011, Asunto C-34-10, Oliver Brüstle contra Greenpeace eV, Apartados 87 a 90.

${ }^{46}$ Conclusiones del Abogado General, Sr. Yves BOT, presentadas en fecha 10 de marzo de 2011, Asunto C-34-10, Oliver Brüstle contra Greenpeace eV, Apartado 91.

${ }^{47}$ Sentencia de 18 de octubre de 2011, Oliver Brüstle/Greenpeace eV, Asunto C-34/10, Apartado 38.

${ }^{48}$ Conclusiones del Abogado General, Sr. Yves BOT, presentadas en fecha 10 de marzo de 2011, Asunto C-34-10, Oliver Brüstle contra Greenpeace eV, Apartado 95. 
mente en garantía de la dignidad humana. Y es que, como afirma el Abogado General,

"esto demuestra la dignidad humana es un principio que debe ser aplicado no sólo a la persona humana existente, al niño nacido, sino igualmente al cuerpo humano desde el primer estadio de desarrollo, es decir, desde la fecundación" 49 .

En cambio, una célula pluripotente, aun cuando haya sido obtenida de un embrión humano, no debe considerarse un embrión, pues carece de la capacidad de desarrollarse para llegar a ser un individuo completo. Estas células deben considerarse "elementos aislados del cuerpo humano", en el sentido del art. 5.2 de la Directiva 98/44/CE.

(ii) Segunda cuestión prejudicial: sobre la utilización de embriones humanos para fines comerciales o industriales

En la segunda cuestión prejudicial, el Bundesgerichtshof pide al Tribunal de Justicia que determine "si el concepto de utilización de embriones humanos para fines industriales o comerciales en el sentido del art.6.2 letra c) de la Directiva engloba la utilización de embriones humanos con fines de investigación médica" ${ }^{50}$.

La respuesta del Tribunal de Luxemburgo comienza recordando que la Directiva no regula la investigación con embriones, sino la patentabilidad de las invenciones biotecnológicas ${ }^{51}$. Dicho esto, pone de manifiesto que las patentes de resultados de investigaciones en las que se hayan utilizado embriones abre la puerta a la explotación con fines industriales y comerciales los citados resultados, pues precisamente el derecho de patentes existe para proteger la explotación industrial y comercial de las invenciones realizadas por particulares ${ }^{52}$.

El Tribunal recuerda que el considerando cuadragésimo segundo de la Directiva, establece una excepción a la prohibición de patentabilidad del art. 6.2.c), al disponer que "no afecta a las invenciones técnicas que tengan un objetivo terapéutico o de diagnóstico que se aplican al embrión y le son útiles". De ahí que concluya señalando que la exclusión de patentabilidad del art. 6.2.c) de la Directiva en relación con la utilización de embriones humanos "también se refiere a la utilización con fines de investigación científica"53.

${ }^{49}$ Conclusiones del Abogado General, Sr. Yves BOT, presentadas en fecha 10 de marzo de 2011, Asunto C-34-10, Oliver Brüstle contra Greenpeace eV, Apartado 96.

${ }^{50}$ Sentencia de 18 de octubre de 2011, Oliver Brüstle/Greenpeace eV, Asunto C-34/10, Apartado 39.

${ }^{51}$ Sentencia de 18 de octubre de 2011, Oliver Brüstle/Greenpeace eV, Asunto C-34/10, Apartado 40.

${ }^{52}$ Sentencia de 18 de octubre de 2011, Oliver Brüstle/Greenpeace eV, Asunto C-34/10, Apartados 41 a 43 .

${ }^{53}$ Sentencia de 18 de octubre de 2011, Oliver Brüstle/Greenpeace eV, Asunto C-34/10, Apartado 46. 
(iii) Tercera cuestión prejudicial: sobre la patentabilidad de invenciones que requieren de la destrucción de embriones humanos o la utilización de los mismos como materia prima.

La última de las cuestiones elevadas por el Tribunal Federal al Tribunal de Justicia plantea si debe excluirse la patente de una invención que, sin tener en sí misma por objeto la utilización de embriones humanos, se refiere a un producto que requiere, para su elaboración, de la previa destrucción de embriones humanos, o a un procedimiento que necesita de materia prima obtenida mediante destrucción de embriones humanos.

A esta cuestión el Tribunal de Justicia responde remitiéndose a los parágrafos 32 a 35 de la Sentencia, concluyendo que "una invención debe considerarse excluida de la patentabilidad, aunque las reivindicaciones de la patente no se refieran a la utilización de embriones humanos, cuando la implementación de la invención requiera la destrucción de embriones humanos"s4, aunque la descripción de la información técnica presentada para obtener la patente no haga referencia alguna a la utilización de embriones humanos.

En relación con este extremo, el Tribunal parece que hace suyo el argumento del Abogado General, para quien conceder la patente en esos supuestos implicaría dejar vació de contenido el art. 6.2.c) de la Directiva, pues para eludir la protección que confiere al embrión lo único que debería hacer el solicitante de la patente es omitir en la información técnica que la invención a patentar ha requerido de la utilización y destrucción de embriones humanos. De ahí que para el Sr. Bot deba excluirse la patentabilidad, pues dar una aplicación industrial a una invención que ha utilizado células madre embrionarias equivaldría a utilizar los embriones humanos como un banal material de trabajo, por lo que se puede concluir que dicha invención estaría instrumentalizando el cuerpo humano, algo expresamente prohibido por la Directiva 98/44/CE 5 .

\section{DIGNIDAD DE LA PERSONA E INVESTIGACIÓN BIOMÉDICA}

Las Sentencias abordadas en el presente trabajo revisten una enorme importancia, en la medida en que confieren un cierto estatuto jurídico al embrión humano, al que extienden la protección del derecho a la dignidad humana del art. 1 de la Carta de derechos fundamentales de la Unión Europea.

En efecto, dentro de las novedades de la codificación de los derechos fundamentales operada por la Carta la doctrina destacó la "sugerente e innovadora" inclusión de derechos relacionados con las nuevas biotecnologías ${ }^{56}$,

\footnotetext{
${ }^{54}$ Sentencia de 18 de octubre de 2011, Oliver Brüstle/Greenpeace eV, Asunto C-34/10, Apartado 49.

${ }^{55}$ Conclusiones del Abogado General, Sr. Yves BOT, presentadas en fecha 10 de marzo de 2011, Asunto C-34-10, Oliver Brüstle contra Greenpeace eV, Apartados 109 y 110.

${ }^{56}$ CARRILlO, M. "La Carta de los derechos fundamentales de la Unión Europea", Revista Vasca de Administración Pública, núm. 65 (II), 2003, p. 156.
} 
elevando a rango de derecho fundamental "normas establecidas en el Convenio del Consejo de Europa de 1997 relativo a los derechos humanos y la biomedicina"57; debe tenerse en cuenta que este es uno de los ámbitos en los que la Carta no se limitó a recopilar o sistematizar derechos ya existentes en el Convenio de Roma o en la propia jurisprudencia comunitaria, sino que procedió a alumbrar nuevos derechos ${ }^{58} \mathrm{o}$ a elevar al máximo rango jurídico a algunos derechos de la biomedicina, estableciendo con ello límites a las prácticas biomédicas para garantizar el derecho a la integridad personal y el respeto a la dignidad humana ${ }^{59}$, hasta el punto de considerarse que el derecho a la integridad reconocido en el art. 3 -concreción del derecho a la dignidad del art. $1^{60}$ - podría llegar "a marcar límites a la investigación biomédica"61.

En consecuencia, las Sentencias del Tribunal de Justicia de la Unión Europea de 9 de octubre de 2001 y de 18 de octubre de 2011 encaran la cuestión del Estatuto del embrión ${ }^{62}$, que es uno de los temas más controvertidos de la bioética contemporánea ${ }^{63}$, y precisamente en un campo especialmente problemático como es la investigación con embriones ${ }^{64}$.

En ambas Sentencias está presente el derecho a la dignidad humana, $\mathrm{y}$-aun cuando de manera no del todo explicitada- de un modo como no ha tenido lugar en ningún otro pronunciamiento jurisprudencial del Tribunal de Luxemburgo. En la primera de ellas, de 9 de octubre de 2001, a pesar de que el Tribunal no hizo referencia alguna a la Carta de derechos fundamentales de la Unión, sí está presente la Carta en la argumentación del Abogado General Sr. Jacobs en sus Conclusiones ${ }^{65}$. Así, el Tribunal de Luxemburgo señaló expresamente que "corresponde al Tribunal de Justicia, al controlar la conformidad de los actos de las

${ }^{57}$ PIRIS, J-C. El Tratado Constitucional para Europa: un análisis jurídico, Marcial Pons, Madrid-Barcelona, 2006, p. 174.

${ }^{58}$ CARTABIA, M. "La escritura de los derechos fundamentales en Europa y los poderes de los jueces”, Revista Vasca de Administración Pública, núm. 73 (I), 2005, p. 55.

${ }^{59}$ MARTÍNEZ MORÁN, N. "El derecho a la integridad de la persona en el marco de la medicina y la biología (en el ámbito de la Unión Europea)", Revista de Derecho de la Unión Europea, núm. 15, 2008, p. 180.

${ }^{60}$ BIFULCO, R. “Articolo 3. Diritto all'integrità della persona”, L'Europa dei diritti, R. BIFULCO, M. CARTABIA, A. CELOTTO. Il Mulino, Bologna, 2001, p. 51.

${ }^{61}$ Editorial. "La Constitución Europea, un núcleo de los derechos humanos de la Medicina y la Biología", Revista Derecho y Genoma Humano, núm. 21, 2004, p. 21.

${ }^{62}$ Cfr. RUBIO NÚNEZ, R. "Investigación con células madre: un problema jurídico", Revista de Derecho Politico, núm. 61, 2004, pp. 229-255.

${ }^{63}$ BERGEL, S. D. "La Directiva Europea 98/44/CE relativa a la protección jurídica de las invenciones biotecnológicas", Revista Derecho y Genoma Humano, núm. 13, 2000, p. 67.

${ }^{64}$ SIMON, J. "La dignidad del hombre como principio regulador en la bioética", Revista Derecho y Genoma Humano, núm. 13, 2000, p. 33.

${ }^{65}$ CELOTTO, A. PISTORIO, G. "L'efficacia giuridica della Carta dei diritti fondamentali dell'Unione Europea (Rassegna giurisprudenziale 2001-2004)", Revista Europea de Derechos Fundamentales, núm. 5, 2005, p. 22. 
instituciones con los principios generales del Derecho comunitario, velar por que se respete el derecho fundamental a la dignidad humana y a la integridad de la persona" ${ }^{\text {"66 }}$, habiendo puesto de manifiesto el Abogado General Jacobs ${ }^{67}$ que "el más fundamental de estos derechos quizá sea el derecho a la dignidad humana, que se consagra en la actualidad en el artículo 1 de la Carta de los derechos fundamentales de la Unión Europea, donde se establece que la dignidad humana es inviolable y será respetada y protegida" ${ }^{\circ}$.

En la segunda de ellas, si bien no aparece de manera expresa en el cuerpo de la Sentencia, el derecho a la dignidad humana está presente de manera extensa en las Conclusiones del Abogado General, Sr. Yves Bot. Podría decirse que, a pesar del tiempo transcurrido, persiste la "presencia silenciosa y no explicitada de la Carta" en la jurisprudencia del Tribunal de Justicia ${ }^{69}$.

Sobre este aspecto, la doctrina ya había puesto de manifiesto que al hablarse en la Carta de derechos fundamentales de "dignidad humana" y no de "dignidad de la persona", era posible incluir dentro de la protección del art. 1 al embrión humano ${ }^{70}$. Y es que, como un embrión "puede desarrollarse hasta llegar a ser una persona", su dignidad debe ser protegida ${ }^{71}$. Esta interpretación

${ }^{66}$ Sentencia de 9 de octubre de 2001, Países Bajos/Comisión, Asunto C-377/98, Apartado 70.

${ }^{67}$ Sobre la relación entre las Conclusiones del Abogado General Jacobs y la naturaleza de la Carta de derechos fundamentales de la Unión Europea puede verse RODRÍGUEZ, A. "Sobre la naturaleza jurídica de la Carta de derechos Fundamentales de la Unión Europea”, Revista de Derecho Político, núm. 51, 2001, especialmente pp. 49-51.

${ }^{68}$ Conclusiones del Abogado General Sr. F. G. JACOBS, presentadas el 14 de junio de 2001, Asunto C-377/98, Reino de los Países Bajos contra Parlamento Europeo y Consejo de la Unión Europea, Apartado 197.

${ }^{69}$ CARTABIA, M. "La escritura de los derechos fundamentales en Europa y los poderes de los jueces", Op. cit., p. 65.

${ }^{70}$ Sobrino Heredia, J. M. "Artículo 1. Dignidad humana", en Carta de los derechos fundamentales de la Unión Europea. Comentario artículo por artículo, Araceli Mangas (Dir.), Fundación BBVA, Bilbao, 2008, p. 124. Al respecto, y a propósito de la garantía de la dignidad humana presente en el art. 1 de la Ley Fundamental (fuente de inspiración del art. 1 de la Carta de derechos fundamentales de la UE), Benda había puesto de manifiesto que aunque las cuestiones relacionadas con la manipulación genética no pudieran ser previstas por la Ley Fundamental, la solución a las mismas no puede ser dejada exclusivamente a instancias políticas. El art. 1 otorga protección frente a cualquier amenaza a la dignidad humana, aun cuando dicha amenaza no existiera en 1949. Ahora bien, esto implica examinar de nuevo cuál es el objeto de protección del art. 1 de la Ley fundamental. Y aunque es cierto que en primer lugar la garantía de la intangibilidad de la dignidad humana protege a las personas actualmente existentes, también se extiende su protección a "lo humano", protegiendo además de este modo a las personas futuras, a las futuras generaciones, que tienen derecho a no ser el producto de la ingeniería genética o copias clónicas de un tercero, sino personas individuales, con todas sus debilidades e imperfecciones. BENDA, E. "The protection of human dignity (Article 1 of the Basic Law)", Fifty Years of German Basic Law, The Johns Hopkins University, Washington, 1999, pp. 43-45.

${ }^{71}$ STARCK, C. "Garantía de la dignidad humana en la práctica de la biomedicina", en Jurisdicción constitucional y derechos fundamentales, Dykinson, Madrid, 2011, p. 223. 
se ve reforzada, a mi entender, por el hecho de que el art. 1 de la Carta va dirigido tanto a la protección de las personas actualmente existentes como a garantizar la protección de aspectos inmateriales, como sería "lo humano" o "la humanidad". Es decir, el derecho a la inviolabilidad de la dignidad humana protege al género humano como especie ${ }^{72}$.

El reconocimiento de la dignidad humana como fundamento de los derechos y como derecho autónomo ${ }^{73}$ implica que "se trata de un principio absoluto e inderogable o permanente que implica que no se puede instrumentalizar jamás a un ser humano, esto es, tratarlo como un mero objeto"74.

En relación con esta cuestión, la primera de las Sentencias analizadas en el presente trabajo excluye la patrimonialización del cuerpo humano, pues la posibilidad de convertirlo en fuente de rendimiento económico conduce a la reducción de la persona a la condición de objeto, lo cual está vedado por el art. 1 de la Carta de derechos fundamentales de la Unión Europea ${ }^{75}$.

Asimismo, debe subrayarse que las Sentencias comentadas huyen del uso retórico de la dignidad o de lo que se ha llamado "inflación de la dignidad", que "conduce de forma inevitable a difuminar aún más el ya de por sí impreciso significado de dicho tópico"76.

$\mathrm{Y}$ es que esta es una de las principales dificultades para elaborar una jurisprudencia de la dignidad; al ser la dignidad humana un concepto jurídico indeterminado, no definible a priori y en abstracto, no es posible establecer una lista tasada de exigencias que se derivan del reconocimiento de la misma como derecho fundamental, sino que sirve de parámetro con el cual confrontar casos concretos surgidos de la experiencia jurídica, de manera que se vulnera

${ }^{72}$ OLIVETTI, M. “Articolo 1. Dignità umana”, L’Europa dei diritti, R. BIFULCO, M. CARTABIA, A. CELOTTO. Il Mulino, Bologna, 2001, pp. 43-44. En nuestra doctrina, ya había considerado Martín Mateo que en las cuestiones bioéticas se debe proteger la "dignidad de la especie"; Cfr. MARTÍN MATEO, R. Bioética y Derecho, Ariel, Barcelona, 1987 , pp. 122 y ss.

${ }^{73}$ En la Explicación oficial del art. 1 de la Carta de derechos fundamentales de la Unión Europea, publicada en el DO C 303, de 14 de diciembre de 2007, se precisa que "la dignidad de la persona humana no sólo es en sí un derecho fundamental, sino que es la base misma de los derechos fundamentales". Sobre la razón de ser y la naturaleza de las Explicaciones oficiales de la Carta, vid., MANGAS, A. "Introducción. El compromiso con los derechos fundamentales", en: ARACELI MANGAS (Dir.). Carta de los derechos fundamentales de la Unión Europea. Comentario artículo por artículo, Fundación BBVA, Bilbao, 2008, pp. 68-70.

${ }^{74}$ Sobrino Heredia, J. M. “Artículo 1. Dignidad humana”, en Araceli Mangas (Dir.), Op. cit., p. 108.

${ }^{75}$ Cfr. MARTÍNEZ SOSPEDRA, M. "La seriedad de los derechos", Revista de Derecho Político, núm. 48-49, 2000, pp. 310-316.

${ }^{76}$ Serna, P. "La dignidad humana en la Constitución europea", en Enrique Álvarez Conde y Vicente Garrido (DiR.). Comentarios a la Constitución Europea, Tirant lo Blanch: Valencia, 2005, Libro II, p. 213. 
la dignidad cuando el ser humano queda degradado a medio para la satisfacción de fines de terceros o a elemento medible y como tal equiparado a una $\operatorname{cosa}^{77}$.

Para salvar esta dificultad, el Tribunal de Justicia ha venido optando por disminuir el recurso al argumento de la dignidad cuanto más controvertida fuera la cuestión a resolver, sin que esto le haya impedido extender la protección de la dignidad en mayor medida a los casos más controvertidos.

En efecto, en la jurisprudencia del Tribunal de Luxemburgo destacan tres Sentencias por el uso que en las mismas se hace del concepto de la dignidad humana: las dos Sentencias relativas a la Directiva 98/44/CE y la Sentencia de 14 de octubre de 2004, Omega Spielhallen-und Automatenaufstellungs$\mathrm{GmbH} /$ Oberbürgermeisterin der Bundesstadt Bonn, Asunto C-36/02.

En la Sentencia sobre el Caso Omega, el Tribunal de Justicia resolvió una cuestión prejudicial planteada por el Tribunal Administrativo Federal de Alemania, en relación con la prohibición de importar un videojuego que tenía por objeto disparar a blancos humanos mediante rayos láser. Pues bien, en esa Sentencia, el Tribunal recurrió al argumento de la protección de la dignidad humana tanto en la ratio decidendi como en el propio fallo. En la ratio decidendi señalando expresamente que para el ordenamiento jurídico comunitario la dignidad humana se trata "innegablemente", de un "principio general del Derecho"78, con la conclusión de poder considerar que "el objetivo de proteger la dignidad humana es compatible con el Derecho comunitario", de manera que puede servir como interés legítimo apto para justificar una restricción a "las obligaciones impuestas por el Derecho comunitario, incluso en virtud de una libertad fundamental garantizada por el Tratado como la libre prestación de servicios"79. En el fallo, al disponer literalmente que "el Derecho comunitario no se opone a que una actividad económica que consiste en la explotación comercial de juegos de simulación de acciones homicidas sea objeto de una medida nacional de prohibición adoptada por motivos de protección del orden público debido a que esta actividad menoscaba la dignidad humana".

Más llamativa es, si cabe, la extensión con que la Abogada General Sra. Stix-Hackl aborda las implicaciones jurídicas de la dignidad humana en sus Conclusiones en el Caso Omega ${ }^{80}$, quien dedica a la cuestión de la dignidad

77 OLIVETTI, M. “Articolo 1. Dignità umana”, Op. cit., p. 44. En el mismo sentido se expresa Pedro Serna en relación con el art. 10 de la Constitución Española, poniendo de manifiesto que prácticamente el único campo en que sí es posible extraer consecuencias jurisprudenciales del principio de dignidad es en el de la "extensión universal del respeto al ser humano". Vid. SERNA, P. "Dignidad de la persona: un estudio jurisprudencial", Persona y Derecho, núm. 41, 1999, p. 194.

${ }^{78}$ Sentencia de 14 de octubre de 2004, Omega Spielhallen- und Automatenaufstellungs$\mathrm{GmbH} /$ Oberbürgermeisterin der Bundesstadt Bonn, Asunto C-36/02, Apartado 34.

${ }^{79}$ Sentencia de 14 de octubre de 2004, Omega Spielhallen- und Automatenaufstellungs$\mathrm{GmbH} /$ Oberbürgermeisterin der Bundesstadt Bonn, Asunto C-36/02, Apartado 35. 
humana en el Derecho comunitario los Apartados 74 a 93, y a la interpretación del concepto de orden público a la luz de la importancia y el alcance de la dignidad humana del 95 al $99^{81}$.

Extensión del recurso a la argumentación a partir del principio de protección de la dignidad humana que la doctrina ha considerado innecesario, pues la restricción a la libertad de prestación de servicios era perfectamente justificable desde la perspectiva de la cláusula de orden público, de manera que el Tribunal podría haber llegado a la misma conclusión sin la mencionada referencia a la dignidad humana ${ }^{82}$.

En la Sentencia de 9 de octubre de $2001^{83}$, el uso del tópico dignidad humana en la ratio decidendi fue, ciertamente, más modesto, a pesar de que puede convenirse sin dificultad que se trataba de un asunto en el que estaba en juego de un modo más evidente la imagen del ser humano en el derecho comunitario. En relación con la patentabilidad de invenciones biomédicas, el Tribunal consideró - en relación con este tema- únicamente que la lista de exclusiones del art. 6 de la Directiva 98/44/CE no es exhaustiva, de ahí que los procedimientos cuya aplicación suponga una violación de la dignidad humana deben también quedar excluidos de la patentabilidad, concluyendo que "la Directiva limita el Derecho de patentes de modo suficientemente estricto para que el cuerpo humano permanezca efectivamente indisponible e inalienable, garantizándose así el respeto de la dignidad humana" ${ }^{\circ 4}$. Del mismo modo, en las Conclusiones del Abogado General Sr. Jacobs en relación con el Asunto C-377/98 tampoco hay excesivas menciones a la dignidad humana. Aparte de la afirmación de que el derecho a la dignidad es "el más fundamental" de los derechos $^{85}$, con especial referencia a la Carta de derechos fundamentales de la Unión, prácticamente se limita a resaltar que el texto de la Directiva, por la

${ }^{80}$ Conclusiones de la Abogado General, Sra. Christine STIX-HACKL, presentadas el 18 de marzo de 2008, Asunto C-36/02, OMEGA Spielhallen- y Automatenaufstellungs$\mathrm{GmbH}$ contra Oberbürgermeisterin der Bundesstadt Bonn.

${ }^{81}$ La Abogada General Sra. STIX-HACKL procede a una completa sistematización del principio de inviolabilidad de la dignidad humana, tanto en la sección dirigida a perfilar los "contornos de la dignidad humana como concepto jurídico" ("expresión del máximo respeto y valor que debe otorgarse al ser humano en virtud de su condición humana", Apartado 75; "constituye el sustrato y el punto de partida de todos los derechos humanos que se diferencian a partir de ella, y a la vez actúa como punto de vista que da perspectiva a los diferentes derechos humanos", Apartado 76) como en la sección en la que aborda la cuestión sobre "la dignidad humana como norma jurídica y su protección en el Derecho comunitario".

${ }^{82}$ CARTABIA, M. "La escritura de los derechos fundamentales en Europa y los poderes de los jueces", Op. cit., pp. 65 y ss.

${ }^{83}$ Sentencia de 9 de octubre de 2001, Países Bajos/Comisión, Asunto C-377/98.

${ }^{84}$ Sentencia de 9 de octubre de 2001, Países Bajos/Comisión, Asunto C-377/98, Apartado 77.

${ }^{85}$ Conclusiones del Abogado General Sr. F. G. JACOBS, presentadas el 14 de junio de 2001, Asunto C-377/98, Reino de los Países Bajos contra Parlamento Europeo y Consejo de la Unión Europea, Apartado 197. 
vía de las exclusiones de la patentabilidad de sus artículos 5 y 6 , "proporciona garantías éticas adecuadas", llegando a la conclusión que "conforme a la Directiva, las invenciones biotecnológicas contrarias a la dignidad humana no son hoy patentables ni podrán serlo en el futuro" $"$.

Por último, en el caso Brüstle contra Greenpeace $\mathrm{eV}$, en la que estaba en cuestión el nivel de protección del embrión humano y por tanto si debe aplicarse el principio de dignidad humana al cuerpo humano desde el primer estadio de su desarrollo (temas de mayor calado que un video juego, aunque se trate de uno que simule el asesinato de seres humanos), encontramos aún menos referencias al principio de dignidad humana.

Así, en la Sentencia de 18 de octubre de 2011 las únicas referencias a la dignidad humana tienen lugar al citar los diferentes Considerandos de la Directiva 98/44/CE que emplean dicho término, y la conclusión -a partir de esas referencias normativas- de que la intención del legislador de la Unión fue "excluir toda posibilidad de patentabilidad en tanto pudiera afectar al debido respeto de la dignidad humana", derivando de esta afirmación que "el concepto de «embrión humano» recogido en el artículo 6, apartado 2 , letra c), de la Directiva debe entenderse en un sentido amplio" ${ }^{87}$. Por su parte, en el Informe de Conclusiones del Abogado General Sr. Bot aparecen tan sólo seis menciones a este concepto, de las cuales cuatro son para recordar el texto de la Directiva o el art. 1 de la Carta de derechos fundamentales de la Unión, mientras que dos de las menciones tienen lugar en apoyo del razonamiento del Abogado General para extender la protección al embrión.

Podríamos decir, entonces, que pareciera que el Tribunal recurre a una suerte de protección de la dignidad sin metafísica, de tal manera que cuanto más controvertido es un asunto (y con independencia de que extienda en cada caso la protección de la dignidad) menor es el recurso a la filosofía. En este sentido, es paradigmática la Sentencia de 18 de octubre de 2011, que se apoya en la protección del cuerpo humano dispuesta en el art. 5 de la Directiva 98/44/CE para excluir la patentabilidad de invenciones biomédicas realizadas a partir de experimentación con embriones.

Esta huida de la filosofía por la "indefinición de la dignidad" 88 se ve paliada en el Caso Brüstle contra Greenpeace eV por el recurso del Abogado General -que en mi opinión asume el Tribunal de Justicia, aun cuando no lo explicite en su Sentencia de 18 de octubre de $2011^{89}$ - al señalar el hecho ob-

${ }^{86}$ Conclusiones del Abogado General Sr. F. G. JACOBS, presentadas el 14 de junio de 2001, Asunto C-377/98, Reino de los Países Bajos contra Parlamento Europeo y Consejo de la Unión Europea, Apartado 227.

${ }^{87}$ Sentencia de 18 de octubre de 2011, Oliver Brüstle/Greenpeace eV, Asunto C-34/10, Apartado 34.

${ }^{88}$ Sobrino Heredia, J. M. “Artículo 1. Dignidad humana”, en: Araceli Mangas (Dir.), Op. cit., 124. 
jetivo e incontrovertido de que las células poseen la capacidad de llegar a convertirse en un cuerpo humano ${ }^{90}$ y ese cuerpo humano está expresamente protegido por la Directiva ${ }^{91}$.

Con otras palabras: si la dignidad humana prohíbe la instrumentalización o cosificación de aquél de quien se predique dicha dignidad ${ }^{92}$, y una estructura celular con capacidad para convertirse en un individuo de la especie humana es un embrión protegido por el derecho a la dignidad, podemos concluir que no es posible reducir a un puro objeto a los embriones ${ }^{93}$. En este sentido, el embrión tiene derecho a un respeto fundado sobre la dignidad humana ${ }^{94}$.

Parece que el Tribunal de Justicia ha acogido la "teoría de la dote" para conceptualizar la dignidad humana, al prescindir de la capacidad de autodeterminación del embrión humano ${ }^{95}$, pues tan solo le basta (i) su pertenencia a la especie humana, y (ii) su capacidad para llegar a ser un individuo humano adulto - de acuerdo con su naturaleza-, para decidir que procede otorgarle protección jurídica.

De ahí que en la Sentencia de 18 de octubre de 2011 el Tribunal excluya la patentabilidad de invenciones que requieren de la utilización de embriones o de células embrionarias, pues de lo contrario, se estaría permitiendo que embrión se convirtiera en un elemento de provecho para terceros, reduciéndolo a la categoría de objeto, que es precisamente lo que prohíbe el derecho

${ }^{89}$ En el mismo sentido se expresa J-R Lacadena. LACADENA, J-R. "La Sentencia del Tribunal de Justicia de la Unión Europea sobre las patentes de células troncales embrionarias. A propósito de un informe jurídico sobre patentes: el concepto y dignidad del embrión humano", Revista de Derecho y Genoma Humano, núm. 35, 2011, p. 156.

${ }^{90}$ Este es el argumento de Robert P. George y Patrick Lee para considerar que los embriones humanos son seres humanos, y que por tanto deben ser objeto de protección jurídica. Cfr. George, R. y Lee, P. “Acorns and Embryos”, The new Atlantis, Winter 2005, 90-100.

${ }^{91}$ De ahí que se haya puesto de manifiesto que la argumentación del Abogado General termine "construyendo una peculiar disociación entre animación y dignidad". Vid. SERRANO RUIZ-CALDERÓN, J. M. "Dignidad versus patenta patentabilidad (Comentario de la STJ 18 de octubre de 2011 en el asunto Brüstle/Greenpeace), Diario La Ley, núm. 7766, Sección Tribuna, de 10 de enero de 2012, p. 4.

${ }^{92}$ En relación con el reconocimiento de la dignidad de la persona operado por el art. 10.1 CE, Jiménez Campo habla de "no instrumentalización" e "interdicción de toda patrimonialización de la persona”. Vid. JIMÉNEZ CAMPO, J. “Art. 10.1 CE. La dignidad de la persona", en: MARÍA EMILIA CASAS BAAMONDE Y MIGUEL RODRÍGUEZ-PIÑERO Y BRAVO-FERRER (dir.), Comentarios a la Constitución, Madrid, Fundación Wolters Kluwer, 2008, pp. 182 y 183.

${ }^{93}$ Vid. asimismo, APARISI Miralles, A. "En torno al principio de la dignidad humana. (A propósito de la investigación con células troncales embrionarias), Cuadernos de Bioética, 2004/2a , 257-282.

${ }^{94}$ RODRÍGUEZ-DRINCOURT ÁlVVAREZ, J., Op. cit., p. 86.

${ }^{95}$ SernA, P. "La dignidad humana en la Constitución europea", Op. cit., 215-217. 
a la dignidad humana ${ }^{96}$. Puede afirmarse, por tanto, que existe un consenso europeo en prohibir la cosificación del embrión ${ }^{97}$.

Por otro lado, llama la atención que el Tribunal de Justicia haya sido más estricto en la aplicación de la garantía de la dignidad para proteger al embrión humano que el Grupo europeo de Ética de la ciencia y de las nuevas tecnologías, que en su dictamen de 7 de mayo de 2002 respaldó la patentabilidad de los inventos biotecnológicos cuyos procedimientos requieran la destrucción de embriones, alegando la protección tanto del interés general presente en la investigación en este campo, -para evitar ralentizar dicha investigación-como el interés particular de los pacientes que pudieran beneficiarse de las aplicaciones de la investigación con embriones ${ }^{98}$.

Ahora bien, en todo caso debe tenerse en cuenta que este avance en el estatuto jurídico del embrión, y la consiguiente protección de su dignidad, tiene lugar a los solos efectos del Derecho de patentes regulado en la Directiva 98/44/CE. Así lo precisa en el parágrafo 49 de sus Conclusiones el Abogado General, Sr. Yves Bot, para quien la conclusión del litigio por lo que respecta a la definición jurídica de embrión en relación al art. 6 de la Directiva, no permite una extensión de dicha definición a otros ámbitos en los que también se encuentra en juego la vida humana, como puede ser el caso del aborto ${ }^{99}$, o la licitud o no de la investigación con embriones.

La precisión tanto del Tribunal de Luxemburgo como del Abogado General Sr. Bot de que el concepto amplio de embrión se refiere únicamente al Derecho europeo de patentes (es decir, dentro del ámbito de competencias de la Unión Europea y en relación con la normativa analizada en el caso con-

${ }^{96}$ StARck, C. "Garantía de la dignidad humana en la práctica de la biomedicina”, $O p$. cit., 228.

${ }^{97}$ BERGEL, S. D. "La Directiva Europea 98/44/CE relativa a la protección jurídica de las invenciones biotecnológicas”, Revista Derecho y Genoma Humano, núm. 13, 2000, p. 67.

${ }^{98}$ Avis du Groupe Européen d'Ethique des Sciences et des Nouvelles Technologies auprès de la Commission Européenne, "Les aspects ethiques de la brevetabilité des inventions impliquant des cellules souches humaines", núm. 6, 7 mai 2002. Disponible en http://ec.europa.eu/bepa/european-group-ethics/docs/avis16 complet fr.pdf, [Consulta: 23/05/2012]. Se trata de un Dictamen a petición de la Comisión Europea, del que son ponentes Linda Nielsen y Peter Whittaker, y al que formula un Voto particular el Profesor Günter Virt.

${ }^{99}$ Entre otros motivos porque, como acertadamente señala el Abogado General Sr. Bot, esa cuestión se sitúa fuera de las competencias de la Unión Europea, por lo que no es objeto del Derecho comunitario. Por lo que respecta al caso del aborto, el Abogado General alude a "legislaciones que tratan de dar soluciones a situaciones individuales dolorosas", algo diferente a la utilización de embriones con fines comerciales e industriales. En el fondo, subyace la idea de que en el caso del aborto estamos ante un caso de ponderación de derechos, entre la vida del nasciturus y la vida o libertad de la madre (a modo de ejemplo, véase el trabajo de Christian Starck antes citado, donde señala que "el óvulo fecundado in vitro no supone una amenaza para nadie" mientras que en el caso del aborto "el nasciturus amenaza la vida de la madre", p. 227). 
creto) es una muestra de la prevención ante el riesgo de un desmesurado activismo judicial que pueda devenir en "colonialismo jurisdiccional" 100 , riesgo ciertamente plausible desde el momento en que una de las consecuencias de la adopción de la Carta de derechos fundamentales de la Unión Europea es el cambio en la propia actividad del Tribunal de Justicia de Luxemburgo, el cual pasa a actuar como tribunal de derechos ${ }^{101}$.

Por tanto, a partir del concepto amplio de embrión acogido en la Sentencia de 18 de octubre de 2011 no es posible cuestionar la validez de las leyes españolas que permiten la investigación con embriones ${ }^{102}$, o que en lugar de acoger un concepto amplio de embrión humano distinguen entre embriones y preembriones ${ }^{103}$.

Sin embargo, lo dispuesto en esta Sentencia sí vincula a los operadores jurídicos a la hora de interpretar la Ley de patentes, la cual excluye de la patentabilidad "las utilizaciones de embriones humanos con fines industriales o comerciales" (art. 5.1.c) y el cuerpo humano, en los diferentes estadios de su constitución y desarrollo" (art. 5.4) ${ }^{104}$.

El resultado no deja de ser paradójico pues, por una parte, será conforme a Derecho -español- y, por lo tanto, lícita la investigación con embriones, aunque el procedimiento de dicha investigación implique la destrucción de los embriones ${ }^{105}$ pero, por otra, en aplicación del Derecho comunitario -y pre-

${ }^{100}$ CARTABIA, M. "La Unión Europea y los derechos fundamentales: 50 años después”, Revista Vasca de Administración Pública, núm. 82 (II), 2008, pp. 99-101.

${ }^{101}$ CARTABIA, M. "L'ora dei diritti fondamentali nll'Unione Euopea", en I diritti in azione. Universalità e pluralismo dei diritti fondamentali nelle Corti europee, Il Mulino, Bologna, 2007, pp. 35 y ss.

${ }^{102}$ Ley 14/2006, de 26 de mayo, sobre técnicas de reproducción humana asistida (especialmente artículos 14 a 16) y Ley 14/2007, de 3 de julio, de Investigación biomédica. Cfr. Serrano Ruiz-CALderón, J. M. Retos jurídicos de la bioética, EIUNSA, Madrid, 2005.

${ }^{103}$ Art. 1.2 de la Ley 14/2006; cfr., asimismo, las SSTC 212/1996, de 19 de diciembre, y 116/1999, de 17 de junio (especialmente en los FFJJ 12 a 15).

${ }^{104}$ Art. 5 de la Ley 11/1986, de 20 de marzo, según redacción dada por la Ley 10/2002, de 29 de abril, por la que se modifica la Ley 11/1986, de 20 de marzo, de Patentes, para la incorporación al Derecho español de la Directiva 98/44/CE del Parlamento Europeo y del Consejo, de 6 de julio, relativa a la protección jurídica de las invenciones biotecnológicas.

${ }^{105}$ En opinión de Pérez del Valle, en la Ley de reproducción humana asistida se desprotege al embrión más de lo que permite la doctrina del Tribunal Constitucional sentada en las Sentencias del Tribunal Constitucional 212/1996 y 116/1999. Cfr. PÉREZ DEL VALLE, C. "Tratamiento jurídico del embrión en la nueva Ley de técnicas de reproducción humana asistida: diagnóstico previo a la implantación, investigación, clonación", en Legislación sobre reproducción asistida: novedades, Cuadernos de Derecho Judicial, XI-2006, 108114. Dudas compartidas por Díez-Picazo, quien ha puesto de manifiesto en relación con la investigación con células madre embrionarias que "para la STC 212/1996 el hecho de que la investigación se realizara con embriones no viables era importante. Por ello, desde un punto de vista constitucional, la pregunta sobre la admisibilidad de la investigación científica con embriones viables está abierta", DÍEZ-PICAZO, L. Mª Sistema de derechos fundamentales, Ed. Civitas, Cizur Menor, 2008, pp. 234-235. 
cisamente para salvaguardar la dignidad humana de los embriones- no será patentable el resultado de dicha investigación.

En todo caso, si los resultados de la investigación no son patentables, es decir, si se excluye el reconocimiento de esos derechos al inventor de cara a su explotación comercial o industrial, parece difícil que los procedimientos de investigación biotecnológica que requieren de la destrucción de embriones humanos obtengan la financiación necesaria para ser realizados. Este hecho puede llevar aparejada la consecuencia de que la industria europea de la biotecnología acabe apostando por investigaciones que, por respetar la dignidad humana de los embriones, sean susceptibles de ser patentadas, precisamente, para una posterior explotación comercial ${ }^{106}$.

De este modo, y he aquí una segunda paradoja, si en sus Conclusiones el Abogado General señaló que la Unión no es sólo un mercado a regular sino que es un espacio con valores que mostrar ${ }^{107}$, parece que serán razones de mercado las que impulsarán un mayor respeto al valor supremo de la dignidad humana.

${ }^{106}$ A juicio de José Miguel Serrano esta es una las consecuencias más importantes de esta Sentencia; cfr. SERRANo RuIZ-CALDERÓn, J. M. "UE: no habrá patentes para células madre embrionarias", Aceprensa, núm. 80/11, 26 de octubre de 2011, p. 2.

${ }^{107}$ Conclusiones del Abogado General, Sr. Yves BOT, presentadas en fecha 10 de marzo de 2011, Asunto C-34-10, Oliver Brüstle contra Greenpeace eV, Apartado 45. 